\title{
Derivative Use by Commercial Banks in Bangladesh
}

\author{
Golam Mohiuddin* \\ Institute of Education, Research and Training, University of Chittagong, Bangladesh \\ *E-mail address: gmuddiniert@cu.ac.bd
}

\begin{abstract}
Derivative use by commercial banks operating in Bangladesh is hypothesized mprove th intermediary functions. The study outcome identifies the influence of derivative on orowth $f$ advances by commercial banks. Bank's participation in advances increases y th increase hed, ing activities through futures. It has also been found that the Bangladeshi privat ector ymerch oanks have a high exposure of risk and have externalized their risk manageme pi Specia zed banks of Bangladesh have a low risk exposure level, but still they have $\mathrm{m}$ derately rnaliz d their risk management practices. Bangladeshi public commercial banks have a deposi and high risk exposure but are still internalizing their risk through risk manag nent. policy nplication of this study is that derivative use by commercial banks is likely to rease the rmediary role of banks, i.e., the increase in advances growth rate rather than iny stment portfolio o owth rate. Commercial banks with large deposit base could gain relatively by e ternalizing their risk management practices since this study reveals that interest rate risk exposure derivative $y$ sers is statistically lesser than non-users.

Keywords: Derivative; hedging; risk managemen rorming assets; credit risk

\section{INTRODUCTION}

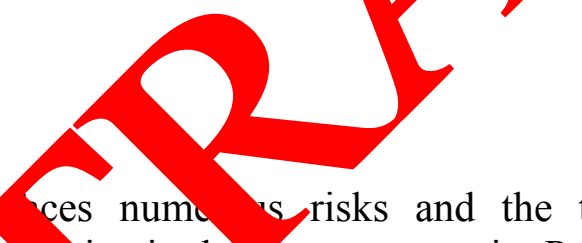

Banking sector ces numb s/risks and the transit towards risk management practices has become mp ive in the present scenario. Present day measured risk could be a potential loss to Jank. measurement of revenue and cost potential of a bank is comparatively parent while t. interest rate risk is not as visible as these tangible revenues and costs. Aelin he interest rate risk management practices for banks has potential incentives to th ctor as vhole in the form of improved profits, capital and integration with econop xpect. ns. Sangladeshi commercial banks have long used risk management acti ties $\mathrm{s}$ h as du. con and gap analysis. Risk management through derivative securities has $n$ lospect for banks to refine risk management practices. Similar to other interna al markets, price and interest rate volatility in Bangladeshi financial markets is high; hen implications of not hedging the bank portfolio may prove to be disastrous. Derivatives give commercial banks an opportunity to manage their risk exposure and to generate revenue beyond that available from traditional bank operations. The study objectives framed to reiterate the importance of risk management practices through derivatives are to examine the derivative exposures in banks and to determine the influence of derivative exposure on bank's intermediation role.
\end{abstract}




\section{LITERATURE REVIEW}

Interest rate volatility and the globalization of capital markets have induced the usage of derivative futures by commercial banks. The competitiveness in the market and the need to identify risk and hedge accordingly requires more coordination in the management of assets and liabilities of these banks. Study on derivatives, especially financial futures, into the balance sheet of banks and as an off-balance sheet hedging tool can be discussed through the works of Ederington (1979), Franckle (1980), Schweser, Cole \& D'Antonio (1980), Arak \& McCurdy (1980) and Morgan \& Smith (1986). They have addressed the use of financial futures and have suggested hedging through interest rate derivatives as an ideal risk management solution. However, focus is more on hedging a cash position in a treasum hill or to hedge an anticipated issue of a Certificates of Deposit (CD). Further stares a d multidimensional aspects to financial intermediary's hedging practices unde onditions uncertainty. Morgan, Shom e \& Smith (1988) considered uncertainties arond a sit supp and loan demand as well as random rate s of return on loans and $C D$ 's. They d so concentrated on the effect of deregulation on interest rate risk borne b rnanc institu ons.

Risk management decisions of banks have been analyzed in ta respect to hedging of bank risks. Allen \& Santomero (2001), K nyap (20 Ba cr \& Ryser (2004) have identified risk management strategies for banks os ortive wo, are Benninga \& Oosterhof (2004), Cebenoyan \& Strahan (2004), S< go ( 2), Danielsson (2002), Nawalkha (2003), Angbazo (1997). Surveys by Bank 10 ntern at 1/Settlement (2002), Basle Committee and IOSCO (1996), are a few in rnational market surveys on derivative practices in banks. Patnaik \& Shah (2003) have $n$ ssured inter st rate risk of a sample of major banks in India using equity capital and marke rice. A m del of the intermediary role of banks and an explanation as to why derivatives lending are complementary activities are validated by Diamond (1984). optimization model for international hedgin in - On dity and currency forward markets. Kim \& Koppenhaver (1992) used bank assets, et-interest margin, derivative dealing, capitalasset ratio and the concentratio rat to test he influence of derivative trading. Brewer, Minton \& Moser (2000) exar. th relations lip between bank participation in derivatives and bank lending and four at banns wing interest-rate derivatives experienced greater growth in their comme and inc loan portfolios than banks that did not use these financial instruments Sho \& Acha, a (1992) and Bernanke \& Lown (1992) have related loan growth with atal to ratio and quality of loan. A bank with too little capital relative to requi ed amount wo not be able to improve its capital position by improving the assets. Simil $\mathrm{V}$ the $\mathrm{n}$ guality if good would induce the bank to increase its loan portfolio the next year. anke \& Lown (1991), Diamond (1984) and Brewer (2000) proposed that derivat ise co hay an influence on the loan portfolio growth.

3. RE ARCHMODEL

Deriyative management process of bank management requires reduction of interest rate risk exposure of banks by increasing the volume of loans and decreasing the volume of deposits. Since loan demand and deposit supply is dependent on interest rates offered, banks can achieve this policy by changing loan and deposit rates to attract loans and dissuade deposits. This process internalizes the market incompleteness of a missing risk sharing market namely derivatives. But, if a derivative market is there for the banks to hedge the bank's exposure, then banks have an opportunity to enter into an unbiased derivative market to externalize their risk exposure. When commercial banks enter a derivative market with an 
expected contract amount for the futures price quotation in the market, this to a certain extent may not require the bank to alter the interest rates beyond a desired level. Hence, through derivatives, the derivative management process is expected to be more efficient. Banks stand to gain operationally as well as from the derivative exposure. Risk exposure, bank size and certain financial parameters are expected to differentiate the derivative users from non-users. Variables that are expected to influence the intermediation role of banks (Growth in advances(AG)) such as Asset Size (LA), Intermediation cost (IC), Credit risk (LQ), Capital adequacy (CA), Investment deposit ratio (ID), Percentage of assets other than advances (OA), Earnings risk (ER), Interest Margin risk (IMR) and derivative growth (DG) are considered for the empirical model.

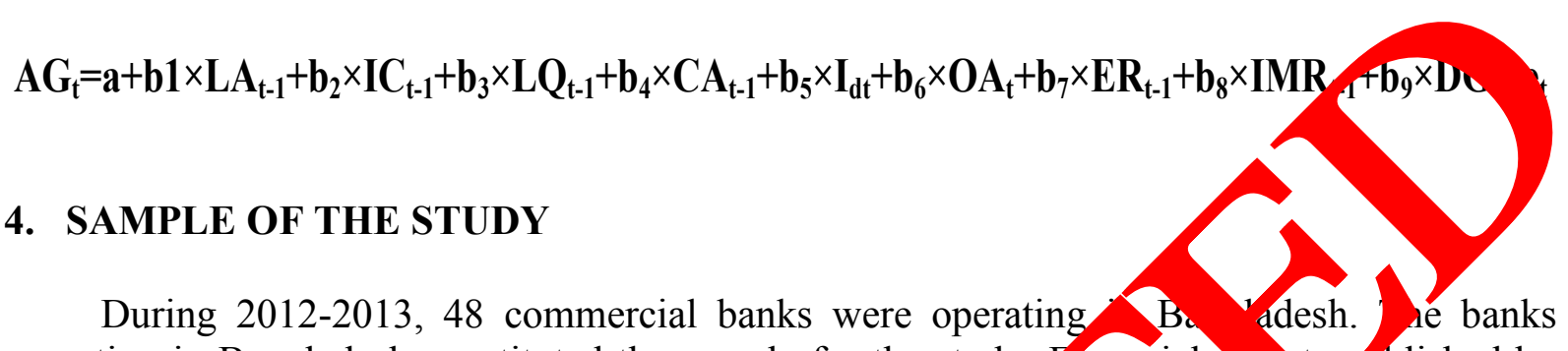
operating in Bangladesh constituted the sample for the study. $y$ nancial ro ts $r$ ablished by banks as made available by the Bangladesh bank constitute $t^{1}$ e for the st $y$. Interest rate sensitivity depends to a large extent on the deposit size o ban esides the public sector banks, both foreign and private Indian banks were al o inoruded in cample. The sample had adequate representation on the basis of size and ctor (Table 1).

Table 1. Sample Char ristics.

\begin{tabular}{|c|c|c|c|c|c|c|c|}
\hline \multicolumn{3}{|c|}{ Deposit size classification } & \multicolumn{5}{|c|}{ ry classification } \\
\hline \multirow{2}{*}{$\begin{array}{c}\text { Bank size } \\
\text { Large banks }\end{array}$} & \multicolumn{2}{|c|}{ Total sample } & $\mathrm{Ca}$ & To & ample & \multicolumn{2}{|c|}{ Derivative users } \\
\hline & 20 & & & 4 & $8.33 \%$ & 3 & $6.25 \%$ \\
\hline Medium banks & 16 & & rivate ba $\mathrm{ks}$ & 24 & $50 \%$ & 19 & $39.58 \%$ \\
\hline Small banks & 12 & & banks & 20 & $41.67 \%$ & 16 & $33.33 \%$ \\
\hline Total & 48 & & Total & 48 & $100 \%$ & 38 & $79.16 \%$ \\
\hline
\end{tabular}

Derivative asos were io ifyed as those banks that reported financial futures exposure consistently ir their oks as an off-balance sheet item during the past five years. Commercial banks that an ot now ny exposure in all the five years were considered as non-users. Additionally wh tanks ad financial futures exposure in only one of the prior five years and no eyposs in the "nt year were considered as partial users and were grouped with nonus Deri ative uses were dominant in the sample (79.16\%).

\section{FINDI, GS OF THE STUDY}

Derivative users showed significant difference from non-users only on the parameter of interest margin risk, which was lower for the derivative users (Table 2). On all other parameters the derivative users and non-users / partial users did not show any statistical significance. Derivative usage has curtailed the interest rate risk exposure of banks operating in Bangladesh. 
Table 2. Parameters Differentiating Derivative Users.

\begin{tabular}{|c|c|c|c|}
\hline Parameters & $\begin{array}{c}\text { Derivative } \\
\text { Users }\end{array}$ & $\begin{array}{c}\text { Derivative } \\
\text { Non-users }\end{array}$ & F-Value \\
\hline Interest margin risk & 0.391 & 0.621 & $4.494^{*}$ \\
\hline Solvency risk & 18.071 & 27.480 & 1.654 \\
\hline Credit risk & 4.108 & 2.524 & 0.107 \\
\hline Earnings risk & 1.207 & 0.960 & 0.289 \\
\hline Business per employees & 479.349 & 413.440 & 0.236 \\
\hline Profit per employee & 4.097 & 2.405 & 0.058 \\
\hline Bank asset size & $25,61,692.17$ & $7,72,045.10$ & 1.101 \\
\hline
\end{tabular}

*Statistical significance at $5 \%$ level

The application of the proposed model to commercial banks usin oriva as hat a statistical good fit. The adjusted $\boldsymbol{R}$ square of the model had an exp anator pow the combined variables as $40.00 \%$. Tolerance test and Variance infla fact $(\boldsymbol{V} \boldsymbol{F})$ do not indicate any multicollinearity among the variables. Adequac of ency, $\mathrm{c}$ edit risk, derivative growth and asset size are significant at $1 \%$ le Deriva 0 wth as an explanatory variable for advances growth has an explanator po of $6.80 \%$ while adequacy of solvency is the prominent influencer with $16.20 \%$ e tonatory wer. Credit risk has a significant explanatory power of $8.20 \%$ (Table 3 ). S andardized beta sefficients are useful when the independent variables representing the $\mathrm{m}$ lel are of different units as in this case. Assuming all other variables of the model are helc onstant, th beta for derivative growth indicates that for every one-unit change in advance rowth, anks enter into a derivative position to the extent of 0.4191 units.

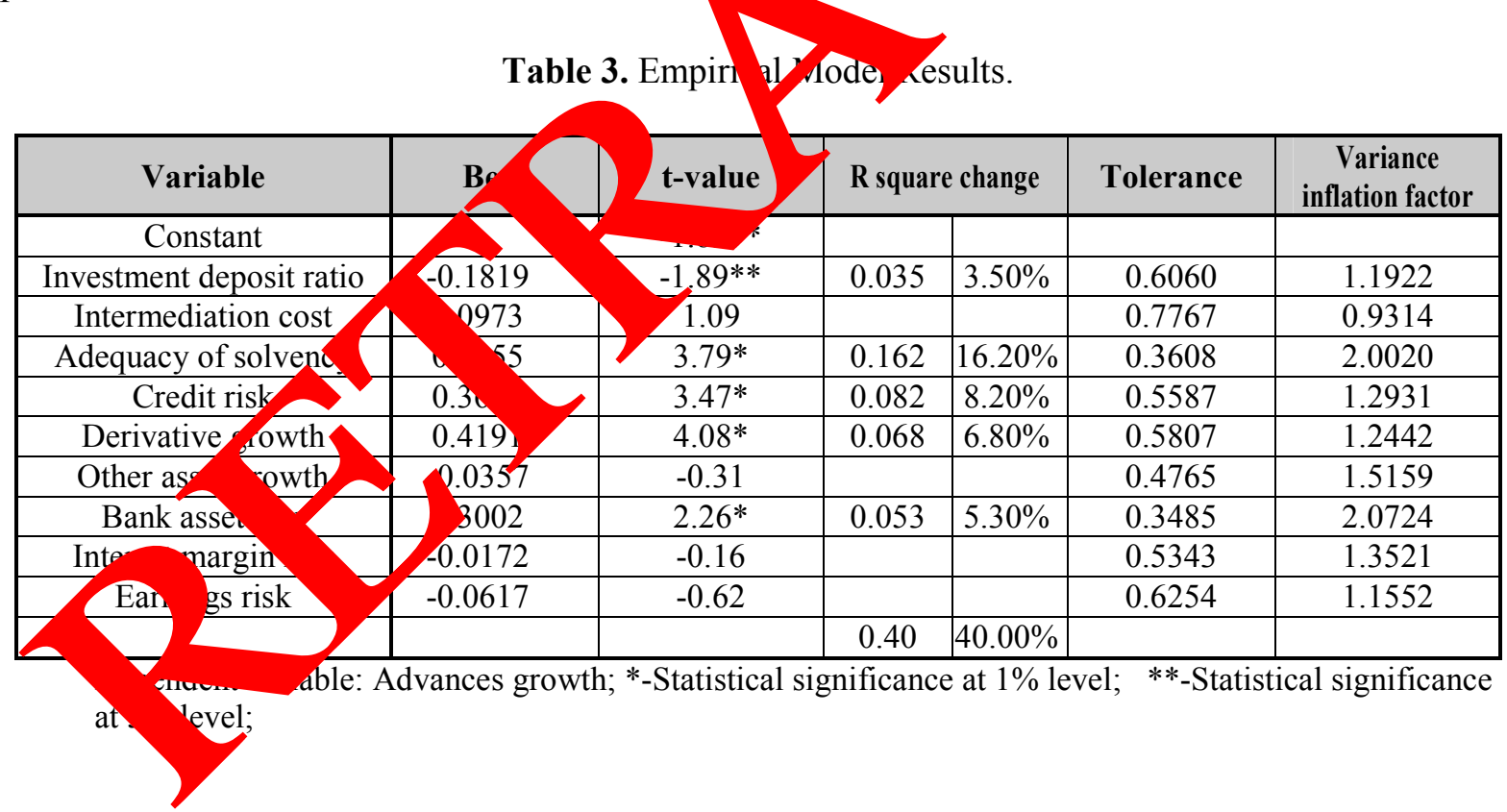

Commercial banks with low capital to asset ratio adjust their lending to meet some predetermined target capital to asset ratio, hence a positive relationship could be expected between capital to asset and advances growth. This has been affirmed in the case of banks operating in Bangladesh. Brewer (2000) reported a positive coefficient between capital to total asset and loan growth. Loan quality if good enables a bank to increase its loan portfolio for the next year. The larger the non-performing assets (NPA), the lower the loan quality and hence the expectation is a negative relationship between loan quality to the advances growth 
next year. However, the positive credit risk coefficient in the model indicates that banks have a higher credit risk exposure and have not improved the loan assessment and recovery process. Lagged total asset is expected to influence advances growth positively. This iterates the experience of bank in lending activities. The beta coefficient in the current model is significant and positive. Investment deposit ratio has a negative beta coefficient as is theoretically expected. Traditionally commercial banks have viewed loans and investment securities as substitutable assets. Consequently, when loan growth strengthens, hypothetical assumption is that banks hold less investment securities. Conversely, larger investment leading to increase in assets results in a negative loan growth. Interest margin risk and earnings risk have the expected negative sign in the equation but are not significant variables. The specific influence of variables could vary due to size differences among banks and ${ }^{1}{ }_{\mathrm{So}}$ in terms of types of banks operating in Bangladesh due their unique operational policies d governance.

\section{LOAN GROWTH INFLUENCERS IN TERMS OF BANK DF OSIT}

The model was applied separately for banks with larger eposit st medam deposit size and smaller deposit size. All three models established s ally goo $h$, but as was expected significant variables were different for each mod Cre risk is the only variable common in all three models (Table 4). Derivate grow ${ }^{+1}$ a signin a the small deposit size banks. The coefficients in all ne models had th similar sign as in the overall model.

Table 4. Model Results - Banks-Classified

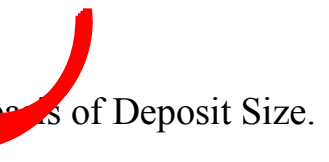

\begin{tabular}{|c|c|c|}
\hline Large size banks & Mediu & Small size banks \\
\hline Credit risk & Cre & Credit risk \\
\hline & Earnit sisk & Adequacy of solvency \\
\hline & ntermedi & Derivative growth \\
\hline
\end{tabular}

\section{LOAN GROW I IN VENCERS IN TERMS OF BANK TYPE}

Three $\mathrm{w}$ dels $y$ re built to examine specific influencers of advances growth in terms of bank type. Al mode showed statistically good fit. Adequacy of solvency was the only variable that in nced dvances growth in all the three models. Public sector banks in addit on phasize lermediation cost for determining the growth of advances. Foreign b2 in a dition co 1 sidered interest margin risk and percentage of other assets. Specialized banks ousum terms of advances and investments as bank assets is low compared to other assets. I could be the reason for the negative statistical significance of other assets in the model for s ecialized banks. Bangladeshi private commercial banks model results are similar to the overall model (Table 5). Operationally, Bangladeshi private commercial banks seem to dominate the banking sector advances growth. This could be due to the competitive environment and introduction of best practices in bank operations. 
Table 5. Model Results - Banks Classified on the basis of Type.

\begin{tabular}{|c|c|c|}
\hline $\begin{array}{c}\text { Nationalized commercial } \\
\text { banks }\end{array}$ & Private commercial banks & Specialized banks \\
\hline Intermediation cost & Intermediation cost & Adequacy of solvency \\
\hline Adequacy of solvency & Interest margin risk & Derivative growth \\
\hline & Percentage of other assets & Credit risk \\
\hline & Adequacy of solvency & Investment deposit ratio \\
\hline & & Bank size \\
\hline
\end{tabular}

\section{RISK EXPOSURE AND RISK MANAGEMENT OF BANKS}

Sub-models built on the basis of deposit size and bank type were in rated rether o identify the risk exposure and risk management practices through co respo dence 1 sis. Private commercial banks are small deposit size banks and have higit posur an have externalized their risk management practices (Figure 1). Banglade on nat lized $\mathrm{c}$ mmercial banks though have a high-risk exposure with a large deposit b have no te nalized their risk management practices and are more traditional in thi resp Special Led banks have low risk exposure and their risk exposure to certain exten veen bernalized.

\section{CONCLUSION}

The study highlighted the use of der in a bank portfolio as an influencer of advances growth. There is a positive relatio shir cen derivative growth and advances growth. Derivative growth significantly influe es the advances growth of small deposit size banks and Bangladeshi private $\mathrm{cmm}$ ial ban. However in all the models derivate growth had a positive sign and this $\mathrm{be}$, ferred a derivatives being used by even nationalized commercial banks and $\mathrm{s}^{\mathrm{r}}$ ial varm os a tool to foster lending activities. Hence, restrictive policy regula ons with ect to bank's derivative activities may lead to lower loan growth rate. Ba gla hi banks port their overall commitment of futures position in their financial rep ts How the distinct usage of different types of derivative products needs to be kno wn to understa the attributes of bank's hedging requirements. A policy on mere usage deriy ve prodacts may not be as convincing as a policy that is based on knowledge of as we as implications of the derivative product usage on the operations of banl This su test, only the implications of the derivative use. This could be further corr borat throug ne type of derivatives used to hedge bank portfolio risk. Further the efro of Livotives use on earnings of banks can be established. This would help in determ g whemer derivative use has resulted in value addition for banks. 


\section{References}

[1] Allen, F. \& A.M.Santomero. What do financial intermediaries do? Journal of Banking and Finance, 25(12), (2001) 271-294.

[2] Angbazo Lazarus. Commercial bank net interest margins, default risk, interest-rate risk, and off-balance sheet banking. Journal of Banking and Finance, 21(1), (1997) $55-87$.

[3] Arak, M. \& C. McCurdy. Interest rate futures. Quarterly Review, Federal Reserve Bank of New York, 4, (1980) 33-46.

[4] Bank for International Settlements. Foreign exchange and derivatives marl a ram in 2001.Triennial Central Bank Survey (2002).

[5] Basle Committee on Banking Supervision and the Technical Comm International Organization of Securities Commissions. Survey of isclosures trading and derivatives activities of banks and securities firms 96).

[6] Bauer, W. \& M. Ryser. Bank risk management strategies Banking and Finance, 28(2), (2004) 331-352.

[7] Benninga, S.R., R. Eldor \& I.Zilcha. Optimal Interna onal loing arid Output Policies in Commodity and Currency Forward Markus. Journo. Sinternational Money and Finance, (1985) 537-552.

[8] Benninga, Simon Z. \& Casper M. Oosterhof. edging witl forwards and puts in complete and incomplete markets. Journal of L ring ar Finance, 28(1), (2004) 117. [9] Bernanke, B.S. \& C.S. Lown. The cre it cr.m rookings Papers on Economic
Activity, 2, (1991) 205-239.

[10] Booth, J.R., R.L.Smith $\&$ W.Si th. The of interest rate futures by financial institutions. Journal of D $R$ (1982) 15-20.

[11] Brewer, E., Berno ette A.M., \& J.T.Moser. Interest-rate derivatives and bank lending. Journ to, anking an inance, 24(3), (2000) 353-379.

[12] Broll, U. \& W.Guin . Interest rate futures and bank hedging. OR Spectrum, 21(1), (999) $71-80$.

[13] Ceben a. Sin \& Philip E. Strahan. Risk management, capital structure and lending a nks. J urnal of Banking and Finance, 28(1), (2004) 19-43.

Cli ord S. W Charles W.Smithson \& Lee M.Wakeman. The market for interest rate cial Management, 17(4), (1988) 34-44.

[15] \ ielsson, Jon, Bjorn N. Jorgensen \& Casper G. de Vries. Incentives for effective risk danagement. Journal of Banking and Finance, 26(7), (2002) 1407-1425.

[16] Diamond, D W. Financial intermediation and delegated monitoring. Review of Economic Studies, 51(3), (1984) 393-414.

[17] Ederington, L. The hedging performance of the new futures markets, Journal of Finance, 34(1), (1979) 157-70.

[18] Franckle, C.T. The hedging performance of the new futures markets: Comment. Journal of Finance, 35(5), (1980) 1273-79. 
[19] Guay, W.R. The impact of derivatives on firm risk: An empirical examination of new derivative users. Journal of Accounting and Economics, (1999) 319-326.

[20] Ho, T. \& A.Saunders. Fixed rate loan commitments, take down risk and the dynamics of hedging with futures. Journal of Financial and Quantitative Analysis, 16, (1983) 499-516.

[21] Kashyap, A.K., R. Rajan \& J.C. Stein. Banks as liquidity providers: An explanation for the coexistence of lending and deposit-taking. Journal of Finance, 57(1), (2002) 33-73.

[22] Kim, S. \& G.D. Koppenhaver. An empirical analysis of bank interest rate swaps. Journal of Financial Services Research, 7, (1992) 57-72.

[23] Koppenhaver, G.D. Bank funding risks, risk aversion, and the choice of tures hedging instrument. Journal of Finance, 40(5), (1985) 241-255.

[24] Moonis, S. A. \& Shah Ajay. A natural experiment in the impact beta (2002).

[25] Morgan, G.E., D.K Shome \& S.D.Smith. Optimal futures firms. Journal of Finance, 43(1), (1988) 175-195.

[26] Morgan, G.E., \& S.Smith. Basis risk, partial take dow and ging by fincial intermediaries. Journal of Banking and Finance, 10, 1986) 40

[27] Mozumdar, A. Corporate hedging and specul ive incentives: Irnplications for swap market default risk. Journal of Financial and uantitative Analysis, 36, (2001) 221250 .

[28] Nawalkha, Sanjay K., Gloria M. Sotd Zhang. Generalized M-vector models for hedging interest rate risk. Journal of B nki s inance, 27(8), (2003) 1581-1604.

[29] Patnaik Ila \& Ajay Shah. In rate v atility and risk in Indian banking. Technical Report 04/17, NCAER a d Mi stry of F ance, (2004).

[30] Rajan, Raghuram \& iay rections in Indian financial sector policy. Technical report niversity Chicago and Ministry of Finance, (2003).

[31] Santomero, A. M eling the oanking firm: A survey. Journal of Money Credit and Banking, 1984$)$ 5, 62.

[32] Schrar a, C., i Unal. Hedging and coordinated risk management: Evidence from thrift conve Ys Journ of Finance, 53(3), (1998) 979-1013.

[33] yartz, \& C.W.Smith. The handbook of currency and interest rate risk ma gement. ew York, New York Institute of Finance (1990).

[34] U.C., J. Cole \& I.D’Antonio. Hedging opportunities in bank risk h. gement programs. Journal of Commercial Bank Lending, 62(1), (1980) 29-41.

[35] Sea cy, C.W. Deposit rate setting, risk aversion and the theory of depository financial intermediaries. Journal of Finance, 35(5), (1981) 1139-1154.

[36] Sharpe, S.A. \& S. Acharya. Loan losses, bank capital and the credit crunch. Federal Reserve Board of Governors, Washington DC (1992).

[37] Stulz, R.M. Rethinking risk management. Journal of Applied Corporate Finance, 9, (1996) 8-24. 
[38] Thomas, Susan, Ajay Shah \& R.L Karandikar. Does the stock market get it before the rating agencies? Some evidence on the Merton model (2002).

[39] Szego, Giorgio. Measures of risk. Journal of Banking and Finance, 26(7), (2002) 1253-1272.

[40] Venkatachalam, M. Value relevance of banks' derivatives disclosures. Journal of Accounting and Economics, 22, (1996) 327-355.

[41] Williams-Stanton, S. The effects of risk-based capital on wealth and risk-taking in banking. Working Paper, Ohio State University, Coloumbus (1996).

[42] Wong, K.P. On the determinants of bank interest margin under credit and interest rate risks. Journal of Banking and Finance, 21(2), (1997) 251-271

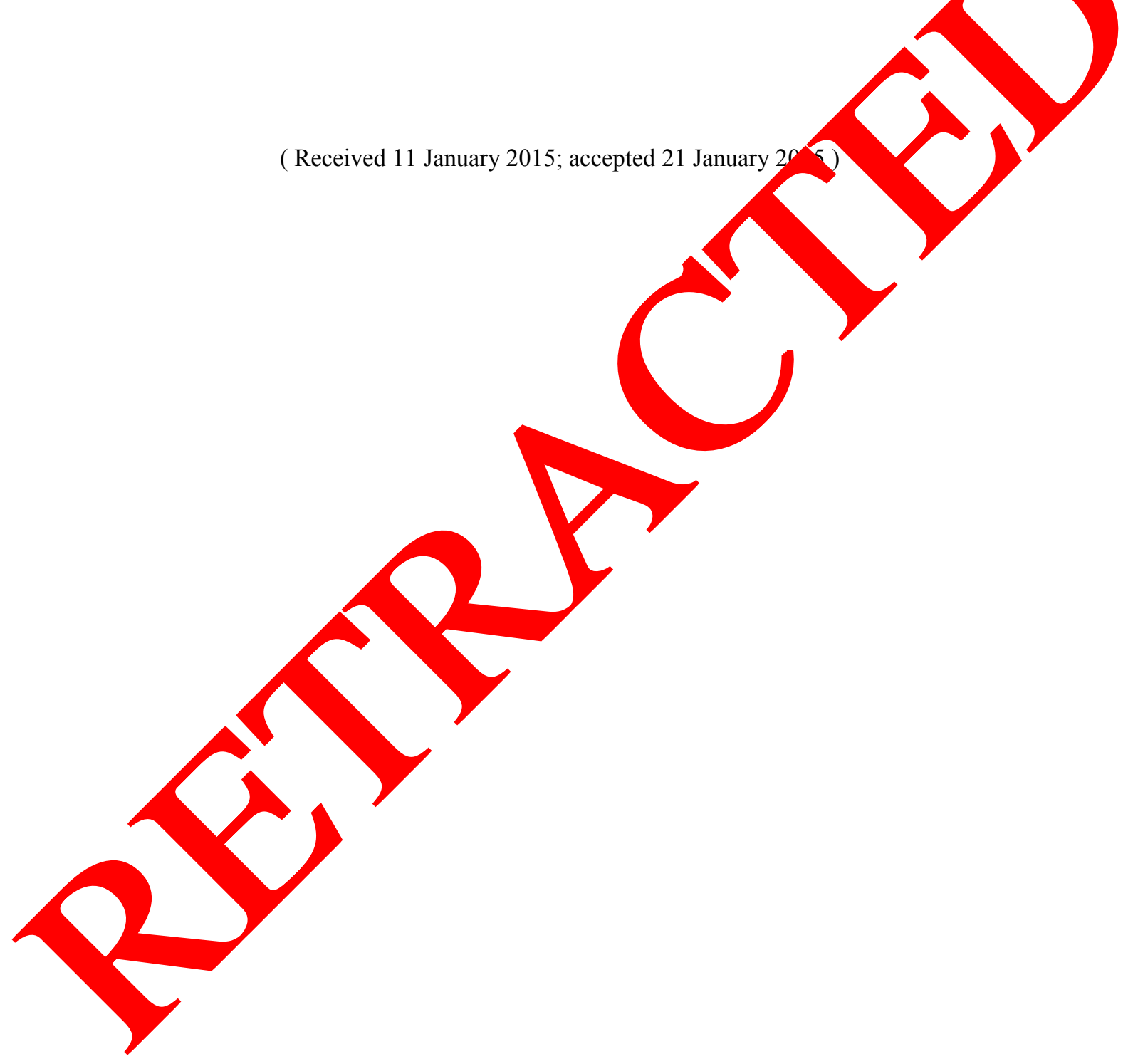

